\title{
Determination of the carbon budget of a pasture: effect of system boundaries and flux uncertainties
}

\author{
Raphael Felber $^{1,2}$, Daniel Bretscher $^{1}$, Andreas Münger ${ }^{3}$, Albrecht Neftel ${ }^{1}$, and Christof Ammann ${ }^{1}$ \\ ${ }^{1}$ Agroscope Research Station, Climate and Air Pollution, Zürich, Switzerland \\ ${ }^{2}$ ETH Zürich, Institute of Agricultural Sciences, Zürich, Switzerland \\ ${ }^{3}$ Agroscope Research Station, Milk and Meat Production, Posieux, Switzerland \\ Correspondence to: Raphael Felber (raphael.felber@agroscope.admin.ch)
}

Received: 24 November 2015 - Published in Biogeosciences Discuss.: 15 December 2015

Revised: 26 April 2016 - Accepted: 9 May 2016 - Published: 19 May 2016

\begin{abstract}
Carbon (C) sequestration in the soil is considered as a potential important mechanism to mitigate greenhouse gas (GHG) emissions of the agricultural sector. It can be quantified by the net ecosystem carbon budget (NECB) describing the change of soil $\mathrm{C}$ as the sum of all relevant import and export fluxes. NECB was investigated here in detail for an intensively grazed dairy pasture in Switzerland. Two budget approaches with different system boundaries were applied: $\mathrm{NECB}_{\text {tot }}$ for system boundaries including the grazing cows and $\mathrm{NECB}_{\text {past }}$ for system boundaries excluding the cows. $\mathrm{CO}_{2}$ and $\mathrm{CH}_{4}$ exchange induced by soil/vegetation processes as well as direct emissions by the animals were derived from eddy covariance measurements. Other C fluxes were either measured (milk yield, concentrate feeding) or derived based on animal performance data (intake, excreta). For the investigated year, both approaches resulted in a small near-neutral $\mathrm{C}$ budget: $\mathrm{NECB}_{\text {tot }}-27 \pm 62$ and $\mathrm{NECB}_{\text {past }} 23 \pm 76 \mathrm{~g} \mathrm{C} \mathrm{m}^{-2} \mathrm{yr}^{-1}$. The considerable uncertainties, depending on the approach, were mainly due to errors in the $\mathrm{CO}_{2}$ exchange or in the animal-related fluxes. The comparison of the NECB results with the annual exchange of other $\mathrm{GHG}$ revealed $\mathrm{CH}_{4}$ emissions from the cows to be the major contributor in terms of $\mathrm{CO}_{2}$ equivalents, but with much lower uncertainty compared to NECB. Although only 1 year of data limit the representativeness of the carbon budget results, they demonstrate the important contribution of the non- $\mathrm{CO}_{2}$ fluxes depending on the chosen system boundaries and the effect of their propagated uncertainty in an exemplary way. The simultaneous application and comparison of both NECB approaches provides a useful consis-
\end{abstract}

tency check for the carbon budget determination and can help to identify and eliminate systematic errors.

\section{Introduction}

The agricultural sector is the third major contributor of anthropogenic induced greenhouse gas (GHG) emissions and accounts for $14 \%$ of global GHG emissions (IPCC, 2014). Depending on the country and the agricultural production system, agriculture can account for more than $50 \%$ of total national GHG emissions (UNFCCC, 2014). While agricultural activities mainly lead to emissions of $\mathrm{CH}_{4}$ and $\mathrm{N}_{2} \mathrm{O}$, agricultural land potentially can be either a source or a sink for atmospheric $\mathrm{CO}_{2}$ (Tubiello et al., 2015) by changing the carbon (C) storage in the soil. Grazing land management, cropland management and restoration of organic soils are considered as the most cost-effective mitigation options for the agriculture sector (IPCC, 2014), and carbon sequestration, i.e., the increase of soil organic carbon (SOC), in grassland is seen as the key issue (Soussana et al., 2010).

To fully account for the GHG effect of an agricultural system, the exchange of all relevant GHGs needs to be determined. Whereas $\mathrm{N}_{2} \mathrm{O}$ and $\mathrm{CH}_{4}$ emissions can be directly measured, the carbon source or sink of an agricultural ecosystem is more difficult to quantify. Changes in SOC can be measured from repeated soil sampling over longer time periods (several years) but are difficult to detect for shorter-term assessments because of the generally large background and high spatial variability (Smith, 2004). For shorter (e.g., annual) timescales the net ecosystem carbon 
balance (NECB) approach can be used (Chapin et al., 2006). It determines the carbon storage change as the net budget of all $\mathrm{C}$ containing import and export fluxes to and from the ecosystem. In natural ecosystems the NECB is mainly determined by the net $\mathrm{CO}_{2}$ exchange with the atmosphere including uptake by photosynthesis and release by plant and soil respiration. In managed agricultural grasslands additional non- $\mathrm{CO}_{2}$ carbon imports (e.g., through manure application) and exports (e.g., through biomass removal) in liquid, solid, or gaseous form are important contributions for the determination of NECB. The NECB of a grazed pasture is also strongly influenced by the $\mathrm{C}$ cycling in the animals.

While the experimental determination of ecosystem $\mathrm{CO}_{2}$ exchange and its problems and uncertainties have been investigated in many publications, only few studies have experimentally assessed the NECB of pasture ecosystems and its quality up to now (e.g., Soussana et al., 2007; Mudge et al., 2011; Rutledge et al., 2015). The GHG exchange of agricultural ecosystems is generally determined and described as flux per surface area, whereas the emission of $\mathrm{CH}_{4}$ and $\mathrm{N}_{2} \mathrm{O}$ of livestock production is often measured or calculated per animal, based on mass or energy budgets as used in the IPCC approaches (IPCC, 2006) followed by up-scaling to national or global GHG emission inventories.

Felber et al. $(2015,2016)$ showed how $\mathrm{CH}_{4}$ and $\mathrm{CO}_{2}$ fluxes over a pasture with grazing dairy cows can be determined using the eddy covariance (EC) technique. Here we combine and complement those measurements with the non-gaseous $\mathrm{C}$ fluxes to determine the annual NECB of the dairy pasture. Two budget approaches with different system boundaries are applied and their advantages and practical limitations (necessary input data and quality) are discussed. To link the NECB and its uncertainty to the full GHG budget of the pasture system, it is compared to the emissions of $\mathrm{CH}_{4}$ and $\mathrm{N}_{2} \mathrm{O}$ in terms of $\mathrm{CO}_{2}$ equivalents.

\section{Material and methods}

\subsection{Study site}

The study site is the same as described in Felber et al. (2015, 2016). The experiment was conducted in 2013 on a pasture field of 3.6 ha at the Agroscope research farm near Posieux on the western Swiss plateau $\left(46^{\circ} 46^{\prime} 04^{\prime \prime} N 7^{\circ} 06^{\prime} 28^{\prime \prime}\right.$ E) at an altitude of $642 \mathrm{~m}$ above sea level with a normal annual rain amount of $1075 \mathrm{~mm}$ and temperature of $8.9^{\circ} \mathrm{C}$ (MeteoSchweiz, 2016). The pasture vegetation consists of a grass-clover mixture (mainly Lolium perenne and Trifolium repens). It was last renovated in August 2007 and has since then been used as pasture for various livestock (dairy, beef cattle, calves). On average the pasture was fertilized with $120 \mathrm{~kg}$ nitrogen $(\mathrm{N})$ per year in addition to the livestock excreta. The soil is classified as stagnic Anthrosol with a loam

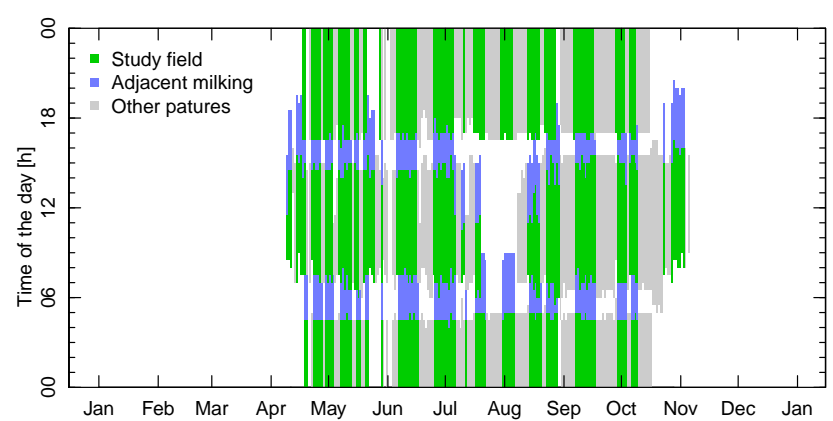

Figure 1. Duration of grazing on the study field (green bars) and for other pastures (gray) over the day and year. The "effective pasture time" of 73.1 days (total of green bars) plus the adjacent "offpasture time" for milking of 25.9 days (blue bars) resulted in "total grazing days" of 99 days. White areas mark other times spent in the barn. White and gray bars are not considered in the budget calculation.

texture and a $\mathrm{C}$ content of the upper soil layer $(0$ to $20 \mathrm{~cm}$ ) of $29 \mathrm{~g} \mathrm{~kg}^{-1}$.

During the grazing season (9 April-4 November 2013) a herd of 20 Holstein and Red Holstein x Simmental crossbred dairy cows with a mean live weight of $640 \pm 70$ (SD) $\mathrm{kg}$ was managed in a rotational grazing system during the day and night. Twice per day the cows left the pasture for milking in the barn (see Fig. 1) where they were also offered concentrate supplements according to their milk production level. Cow positions were recorded by GPS devices to determine pasture presence time on a $30 \mathrm{~min}$ basis. The pasture was divided into six paddocks of equal size and were grazed for 1 to 3 days depending on herbage height. Grazing was interrupted in some cases due to unfavorable environmental conditions (risk of frost, too high temperatures, or too wet soil conditions). The fodder provided by the 3.6 ha study field was not sufficient for continuous grazing of the herd during the entire season. Therefore, additional pasture was needed for certain periods. However, the budget calculations applied here only consider carbon fluxes related to the specific study pasture.

\subsection{Carbon budget concept}

In agricultural ecosystems the change of the SOC stock over time represents a sink or source of atmospheric $\mathrm{CO}_{2}$. The effect of changes in living plant biomass can often be neglected (due to the lack of woody biomass accumulation) when looking at full years including a complete vegetation season or longer periods. With the NECB approach, the SOC stock change is determined by closing the carbon mass budget of the ecosystem:

$\frac{\Delta \mathrm{SOC}}{\Delta t \cdot A} \approx \mathrm{NECB} \equiv \sum_{x} F_{\mathrm{C}-x}$,

where $A$ is the surface area under consideration and $F_{\mathrm{C}-x}$ are all relevant carbon mass exchange fluxes through the ecosys- 
(a)

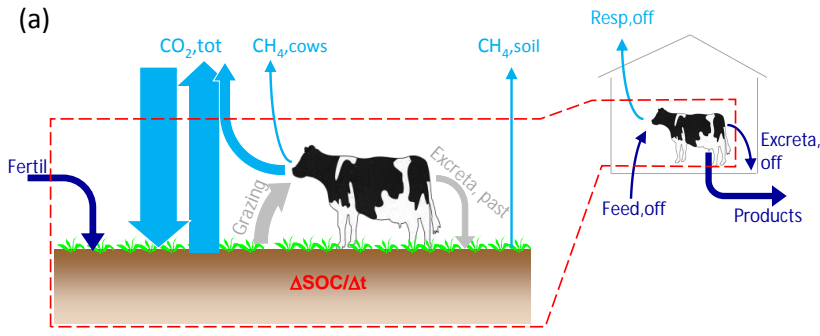

(b)

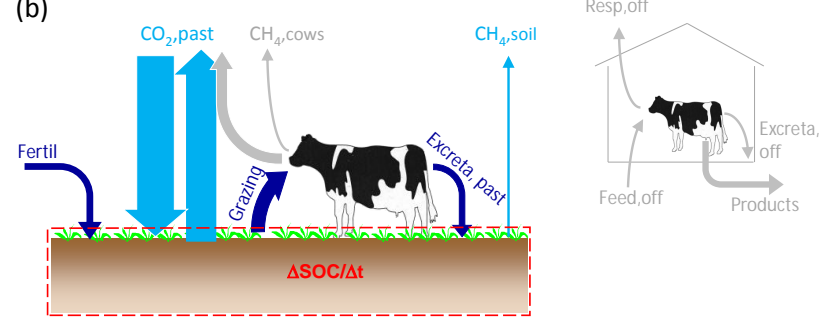

Figure 2. Illustration of the two approaches to determine the net ecosystem carbon budget of a dairy pasture using different system boundaries (dashed red line): (a) $\mathrm{NECB}_{\text {tot }}$ using system boundaries including the cows; (b) $\mathrm{NECB}_{\text {past }}$ using system boundaries excluding the cows. Relevant carbon fluxes through the system boundaries are marked in blue (gaseous fluxes: light blue, liquid/solid fluxes: dark blue).

tem boundaries by various pathways $x$ (in gaseous, liquid, or solid form). Here we follow the ecological sign convention, in which positive flux and NECB values indicate a $\mathrm{C}$ uptake by the system and negative values a $\mathrm{C}$ loss from the system (Chapin et al., 2006). In the present study we determined the NECB for a full calendar year. This is a common procedure in temperate and boreal regions of the northern hemisphere with start/end in the winter season to avoid effects of carbon storage in living plant biomass and of uncertainties in the attribution of management-related fluxes.

For dairy pasture systems, the choice of system boundaries for the determination of the NECB is not as obvious as for other ecosystems, because of the (temporal) presence of the grazing animals. Two approaches with different boundaries were chosen here to estimate the change of SOC stock expressed as NECB (Fig. 2). In these budget calculations, we neglect $\mathrm{C}$ loss due to leaching and erosion because they could not be measured in this experiment, and are assumed to be very small compared to the major fluxes.

The first approach (Fig. 2a) deduces the carbon budget from all relevant $\mathrm{C}$ fluxes of the total system including the grazing animals $\left(\mathrm{NECB}_{\text {tot }}\right)$ similar as applied by Soussana et al. (2007) and Rutledge et al. (2015). In this approach animal respiration and products count as $\mathrm{C}$ exports, beside other $\mathrm{C}$ losses from the pasture. Since the cows had to leave the pasture twice a day for milking in the barn, this system also comprises cow fluxes during these off-pasture phases. $\mathrm{NECB}_{\text {tot }}$ is determined as

$$
\begin{aligned}
\mathrm{NECB}_{\text {tot }} & =F_{\mathrm{C}_{-} \mathrm{CO}_{2}, \text { tot }}+F_{\mathrm{C}-\mathrm{CH}_{4}, \text { soil }}+F_{\mathrm{C}_{-} \mathrm{CH}_{4}, \text { cows }} \\
& +F_{\mathrm{C} \text {-fertil }}+F_{\mathrm{C} \text {-products }}+F_{\mathrm{C} \text {-feed,off }} \\
& +F_{\mathrm{C} \text {-resp,off }}+F_{\mathrm{C} \text {-excreta,off }},
\end{aligned}
$$

where $F_{\mathrm{C}_{-} \mathrm{CO}_{2} \text {,tot }}$ is the net $\mathrm{CO}_{2}$ exchange of the total grazing system including cow respiration (during their presence on

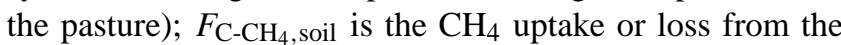
soil including deposited dung on the pasture and $F_{\mathrm{C}_{-} \mathrm{CH}_{4} \text {,cows }}$ is the $\mathrm{CH}_{4}$ emission from enteric fermentation; $F_{\mathrm{C}-\text { fertil }}$ is the imported $\mathrm{C}$ in organic fertilizers, and $F_{\mathrm{C} \text {-products }}$ is the $\mathrm{C}$ exported in animal products milk and meat (live weight gain). It has to be noted that the $\mathrm{C}$ stock change in animal live weight is treated here as an export flux and thus it is not part of the resulting net ecosystem budget. For the time share the cows spent off-pasture, the intake of supplementary feed $\left(F_{\mathrm{C} \text {-feed,off }}\right)$ as well as the loss by animal respiration $\left(F_{\mathrm{C} \text {-resp,off }}\right)$ and excreta $\left(F_{\mathrm{C} \text {-excreta,off }}\right)$ are considered.

The system boundaries of the second approach $\left(\mathrm{NECB}_{\text {past }}\right.$, Fig. 2b) comprise only the pasture (soil and vegetation); the cows are outside the system but contribute to the budget by exporting forage and importing excreta. This approach has been applied, e.g., by Skinner (2008). NECB past $_{\text {is deter- }}$ mined as

$$
\begin{aligned}
\mathrm{NECB}_{\text {past }} & =F_{\mathrm{C}_{-} \mathrm{CO}_{2}, \text { past }}+F_{\mathrm{C}-\mathrm{CH}_{4}, \text { soil }}+F_{\mathrm{C} \text {-fertil }} \\
& +F_{\mathrm{C} \text {-grazing }}+F_{\mathrm{C} \text {-excreta,past }},
\end{aligned}
$$

where $F_{\mathrm{C}-\mathrm{CO}_{2} \text {,past }}$ is the net $\mathrm{CO}_{2}$ exchange of the pasture without cow respiration; $F_{\mathrm{C} \text {-grazing }}$ is grass biomass $\mathrm{C}$ removed by grazing, and $F_{\mathrm{C} \text {-excreta,past }}$ is the $\mathrm{C}$ import by excreta on the pasture.

The individual flux terms contributing to the budgets in Eqs. (2) and (3) act for different time periods; fluxes related to the pasture field act for the full year (i.e., $\left.F_{\mathrm{C}_{-} \mathrm{CO}_{2} \text {,tot }}, F_{\mathrm{C}_{-} \mathrm{CO}_{2} \text {,past }}, F_{\mathrm{C}-\mathrm{CH}_{4} \text {, soil }}, F_{\mathrm{C} \text {-fertil }}\right)$, while the cowrelated fluxes act only for the time periods associated with grazing on the investigated pasture (including the adjacent milking time) and were calculated as the attributed temporal fraction. In the study year the cows grazed for a total of 99 days on the investigated pasture (hereafter referred to as "total grazing days", see Fig. 1) applying to $F_{\mathrm{C}-\mathrm{CH}_{4} \text {,cows, }}$ $F_{\text {C-grazing }}, F_{\mathrm{C} \text {-products }}$, and $F_{\mathrm{C} \text {-feed,off }}$ (see Table $\mathrm{S} 2$ in the $\mathrm{Sup}$ plement). Even on these grazing days, the cows had to leave the pasture and go to the barn twice a day for milking. The average time for one milking event (including the time for moving between pasture and barn, indicated by the GPS position) was $3.1 \mathrm{~h}$. Thus the effective time spent on the investigated pasture was reduced to 73.1 days (hereafter referred to as "effective pasture time"), applying to $F_{\text {C-excreta,past }}$. The complementary "off-pasture time" of 25.9 days applies to $F_{\mathrm{C} \text {-resp,off }}$ and $F_{\mathrm{C} \text {-excreta,off. }}$

Annual animal-related $\mathrm{C}$ fluxes were aggregated from average daily animal exchange rates $E_{\mathrm{C}-x}$ (in units 
of $\mathrm{gChead}^{-1} \mathrm{~d}^{-1}$ ) over the mean number of animals $\left(n_{\text {cow }}=19.7\right)$ and allocated to the total pasture area $\left(A=36000 \mathrm{~m}^{2}\right)$ :

$F_{\mathrm{C}-x}=E_{\mathrm{C}-x} \cdot \frac{n_{\mathrm{cow}}}{A} \cdot T_{x}$,

where $T_{x}$ is the accountable time period for the flux $F_{\mathrm{C}-x}$ as described above. The sign may change between $F_{\mathrm{C}-x}$ and $E_{\mathrm{C}-x}$ depending on the examined system boundaries. The uncertainty of the NECB was calculated by Gaussian error propagation of the individual uncertainties of the fluxes contributing to the budget. A detailed description of the individual error determination can be found in the Supplement, if not specified in the main text.

\subsection{Determination of area-related fluxes}

\subsection{1 $\mathrm{CO}_{2}$ fluxes}

Net $\mathrm{CO}_{2}$ exchange of the pasture was determined as net ecosystem exchange (NEE) using the EC technique as described in Felber et al. (2016). NEE was determined under the micrometeorological sign convention (negative for downward/uptake, positive for upward/loss), thus $F_{\mathrm{C}_{-} \mathrm{CO}_{2}}$ used here has the opposite sign of NEE. Annual $F_{\mathrm{C}_{-} \mathrm{CO}_{2}}$ was calculated either from gap-filled flux data including cases with cow respiration $\left(F_{\mathrm{C}-\mathrm{CO}_{2} \text {, tot }}\right)$ or only from data without cow respiration contribution $\left(F_{\mathrm{C}_{-} \mathrm{CO}_{2} \text {,past }}\right)$. The selec-

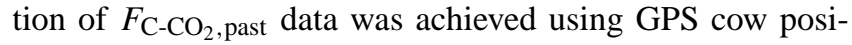
tion information and the flux footprint distribution. The uncertainties of the annual $\mathrm{CO}_{2}$ fluxes were determined from combined random and systematic uncertainties. Random uncertainty was estimated from varying the input data before gap filling (adding random noise or additional gaps) and systematic uncertainty was estimated from varying the applied selection threshold for low-turbulence conditions ( $u_{*}$ filtering). The difference between the $F_{\mathrm{C}-\mathrm{CO}_{2} \text {,tot and }}$ $F_{\mathrm{C}-\mathrm{CO}_{2} \text {,past }}$ corresponds to the area-related cow respiration flux, which could be converted to an average cow respiration $E_{\text {C-resp }}=4.6 \mathrm{~kg} \mathrm{Chead}^{-1} \mathrm{~d}^{-1}$. Felber et al. (2016) estimated different uncertainties for cow respiration, here we use the rather conservative uncertainty of $\pm 1.6 \mathrm{~kg} \mathrm{C}_{\text {head }}{ }^{-1} \mathrm{~d}^{-1}$.

\subsection{2 $\mathrm{CH}_{4}$ fluxes}

$\mathrm{CH}_{4}$ emissions of the pasture soil and surface $\left(F_{\mathrm{C}-\mathrm{CH}_{4} \text {,soil }}\right)$ were determined from EC data without direct cow influence (for details see Felber et al., 2015). Flux intervals were selected based on GPS data of cow positions. Small, generally positive fluxes in a typical range of 0 to $15 \mathrm{nmol} \mathrm{m}^{-2} \mathrm{~s}^{-1}$ were found. Even though some temporal variations in median diurnal and seasonal cycles were observed, a constant soil/surface $\mathrm{CH}_{4}$ emission over the year of $4 \pm 3 \mathrm{nmol} \mathrm{m}^{-2} \mathrm{~s}^{-1}$ is assumed for the budget calculation. This value integrates emissions induced from cow excreta and $\mathrm{CH}_{4}$ sources and sinks of the soil. The uncertainty of the pasture $\mathrm{CH}_{4}$ fluxes was estimated from the uncertainty range of $\pm 50 \%$ covering the temporal variation of weekly medians.

Felber et al. (2015) also determined in situ animal $\mathrm{CH}_{4}$ emissions from EC data. Cow $\mathrm{CH}_{4}$ fluxes were corrected by the weights of individual cow position contributions to convert area integrated data into emissions per animal. The average animal $\mathrm{CH}_{4}$ emission amounted to $423 \pm 24 \mathrm{~g} \mathrm{CH}_{4}$ head $^{-1} \mathrm{~d}^{-1}$. This seasonal average animal exchange rate was converted to a carbon exchange and back to a corresponding area-related flux $F_{\mathrm{C}-\mathrm{CH}_{4} \text {, cows }}$ using Eq. (4) for the timespan of total grazing days.

\subsubsection{Fertilizer application}

In the study year, two fertilizer applications took place: Before the beginning of the grazing season (6 March) cattle slurry was applied by trailing hose at a rate of $43 \mathrm{~m}^{3} \mathrm{ha}^{-1}$. Dry organic matter of the slurry was determined according to VDLUFA (2000) recommendations and the C content of the dry matter of $52 \%$ was adopted from previous comparisons with elemental analysis for a similar slurry. The uncertainty of the slurry $\mathrm{C}$ import was assumed to be $17 \%$ (Ammann et al., 2009). Nitrogen applied by the slurry amounted to $70 \mathrm{~kg} \mathrm{~N} \mathrm{ha}^{-1}$. An additional $50 \mathrm{~kg} \mathrm{Nha}^{-1}$ was applied as urea in June. Due to the $\mathrm{C} / \mathrm{N}$ ratio of $1 / 2$ in urea, this corresponds to a very small $\mathrm{C}$ import.

\subsection{Determination of animal-related fluxes}

The animal-related carbon fluxes can be examined under the aspect of the animal $\mathrm{C}$ budget (in units $\mathrm{g} \mathrm{Chead}^{-1} \mathrm{~d}^{-1}$ ) balancing gain with loss and storage terms:

$$
\begin{aligned}
E_{\mathrm{C} \text {-intake }} & =E_{\mathrm{C} \text {-resp }}+E_{\mathrm{C}-\mathrm{CH}_{4}, \text { cow }}+E_{\mathrm{C} \text {-milk }}+E_{\mathrm{C} \text {-meat }} \\
& +E_{\mathrm{C} \text {-excreta. }} .
\end{aligned}
$$

Ingested $\mathrm{C}$ in feed $\left(E_{\mathrm{C} \text {-intake }}=E_{\mathrm{C} \text {-grazing }}+E_{\mathrm{C} \text {-feed,off }}\right)$ is partitioned into respired $\mathrm{CO}_{2}\left(E_{\mathrm{C} \text {-resp }}\right)$, loss of $\mathrm{CH}_{4}$ by enteric fermentation $\left(E_{\mathrm{C}-\mathrm{CH}_{4}, \text { cow }}\right)$, the $\mathrm{C}$ in milk $\left(E_{\mathrm{C} \text {-milk }}\right)$ and live weight gain $\left(E_{\mathrm{C} \text {-meat }}\right)$, and the $\mathrm{C}$ in the excreta $\left(E_{\mathrm{C} \text {-excreta }}\right)$. The determination of $E_{\mathrm{C} \text {-resp }}$ and $E_{\mathrm{C}-\mathrm{CH}_{4} \text {,cow }}$ was already described in the previous sections. The quantification of the other terms is explained in the following.

\subsubsection{Products}

The animal production terms $E_{\mathrm{C} \text {-milk }}$ and $E_{\mathrm{C} \text {-meat }}$ were estimated from monitored daily milk yield and live weights measured after milking. Milk was sampled individually on 1 day per week and analyzed for fat, protein and lactose content. Energy-corrected milk yields (ECM) adjusted to a gross energy content of $3.14 \mathrm{MJ} \mathrm{kg}^{-1}$ were calculated from daily milk yields according to Arrigo et al. (1999) using fat, protein and lactose contents. The $\mathrm{C}$ content was calculated using an energy to $\mathrm{C}$ content ratio of $21 \pm 1.9 \mathrm{~g} \mathrm{C} \mathrm{MJ}^{-1}$ (for details 
see Sect. S1.2 in the Supplement). Using data from the entire grazing period an average milk $\mathrm{C}$ output per cow and day $\left(E_{\mathrm{C} \text {-milk }}\right)$ was derived with an uncertainty of $9 \%$.

The live weight (LW) of the dairy cows slightly increased by around $6 \%$ over the entire grazing season of 209 days corresponding to an average daily increase of $0.2 \mathrm{~kg} \mathrm{LW} \mathrm{head}{ }^{-1} \mathrm{~d}^{-1}$. Applying the value of $0.14 \mathrm{~kg} \mathrm{C}(\mathrm{kg}$ fresh meat) ${ }^{-1}$ (Avila, 2006) the $\mathrm{C}$ incorporated into meat results in $0.025 \mathrm{~kg} \mathrm{Chead}^{-1} \mathrm{~d}^{-1}$, which is less than $2 \%$ of milk $\mathrm{C}$ yield and thus negligible here. Even for beef cattle, $E_{\mathrm{C} \text {-meat }}$ is generally small (Allard et al., 2007) and thus sometimes neglected in carbon budget calculations (e.g., Soussana et al., 2007).

$F_{\mathrm{C} \text {-products }}$ was calculated from $E_{\mathrm{C} \text {-milk }}$ by Eq. (4) using the number of total grazing days.

\subsubsection{Feed intake}

The dry matter (DM) feed of the cows was estimated using two different approaches: (i) by the Tier 2 model given in the IPCC Guidelines (IPCC, 2006) and (ii) based on the Swiss feeding recommendations and nutrition tables for ruminants (Arrigo et al., 1999). The former approach estimates gross energy intake of the cows from net energy requirements for maintenance, activity (grazing), and production (milk yield). The gross energy intake is then converted to DM intake using the default factor of $18.45 \mathrm{MJ}(\mathrm{kg} \mathrm{DM})^{-1}$ (IPCC, 2006). The second model uses the following equations (Eq. (6a) for primiparous and Eq. (6b) for multiparous cows):

$$
\begin{gathered}
E_{\text {DM-intake }}=0.33 \cdot \mathrm{ECM}+0.29 \cdot \mathrm{lacW}-0.0047 \\
\cdot \mathrm{lacW}^{2}+6.0 \\
E_{\text {DM-intake }}=0.33 \cdot \mathrm{ECM}+0.17 \cdot \mathrm{lacW}-0.0025 \\
\cdot \mathrm{lacW}^{2}+8.8,
\end{gathered}
$$

where ECM is in $\mathrm{kg} \mathrm{head}^{-1} \mathrm{~d}^{-1}$ and lacW is the actual lactation week of the cow. Additional intake corrections were applied for deviations from standard live weight (600 and $650 \mathrm{~kg} \mathrm{LW}$ for Eqs. 6a, b, respectively) and standard annual milk production (6500 and $7500 \mathrm{~kg}$ respectively). Estimated

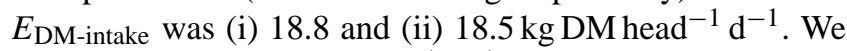
used $18.5 \pm 2.7 \mathrm{~kg} \mathrm{DM} \mathrm{head}^{-1} \mathrm{~d}^{-1}$ for the further calculations because this value is based on the actual production state of the cows in contrast to the value from approach (i), which is based on the IPCC standard parameterization.

Besides the grazing on the pasture, the cows were offered a minor amount of supplement feeding (concentrates) depending on individual milk production level of each cow. Daily concentrate intake was recorded for each cow, on average it amounted to $1.3 \pm 0.2 \mathrm{~kg} \mathrm{DM} \mathrm{head}^{-1} \mathrm{~d}^{-1}$ over the grazing period.

Carbon (and N) content of pasture forage and concentrates were measured by dry combustion (VDLUFA, 2000) of weekly sampled pasture forage and from periodically analyzed concentrate samples ( $n=6$ over the grazing period). A carbon content of $433 \pm 9 \mathrm{gC}(\mathrm{kg} \mathrm{DM})^{-1}$ was measured for pasture forage and $430 \pm 9 \mathrm{gC}(\mathrm{kg} \mathrm{DM})^{-1}$ for the concentrates. With this information the total average daily carbon intake $\left(E_{\mathrm{C} \text {-intake }}\right)$ per cow was derived. $F_{\mathrm{C} \text {-feed,off was calcu- }}$ lated from the daily concentrate intake alone. $F_{\mathrm{C} \text {-grazing }}$ was calculated for the total grazing days from the difference between $E_{\mathrm{C} \text {-intake }}$ and $E_{\mathrm{C} \text {-feed,off with an uncertainty of } \pm 16 \%}$ (see Table S2).

\subsubsection{Excreta}

Excreta output could not be measured directly in this study, and it is generally difficult to measure for grazing animals. But the ratio of $E_{\mathrm{C} \text {-excreta }}$ relative to the animal intake was estimated from the analysis of the feed digestibility. For this purpose, 50 grass samples taken during the grazing season were analyzed by Tilley and Terry (1963). This resulted in an average feed organic matter digestibility of 0.72 with an uncertainty range of \pm 0.07 . Because the carbon content in the excreted dung (c. $50 \%$ of organic matter, see e.g., Pettygrove et al., 2010) is higher than in the feed (43\% of organic matter acc. to sample analysis) the effective carbon digestibility reduces to 0.68 . Accordingly $E_{\mathrm{C} \text {-excreta }}$ was estimated as $32 \pm 8 \%$ of the animal carbon intake. $F_{\mathrm{C} \text {-excreta,past }}$

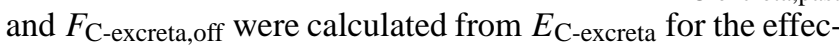
tive pasture time and the off-pasture time, respectively, using Eq. (4).

\subsection{Comparison to other pasture greenhouse gas fluxes}

For a quantitative comparison of the NECB to the other relevant GHG fluxes of the pasture system, the $\mathrm{CH}_{4}$ and $\mathrm{N}_{2} \mathrm{O}$ emissions were converted to $\mathrm{CO}_{2}$ equivalents based on their global warming potential (GWP). Here we used the 100year GWPs; $25 \mathrm{CO}_{2}$-eq. for $\mathrm{CH}_{4}$ and $298 \mathrm{CO}_{2}$-eq. for $\mathrm{N}_{2} \mathrm{O}$ (Solomon et al., 2007). The system boundaries were the same as for the determination of the $\mathrm{NECB}_{\text {tot }}$, i.e., the effects of the investigated pasture including the animals during pasture days are taken into account. Correspondingly, area-related fluxes are accounted for the entire year, while cow-related fluxes are accounted for the total pasture days (time spent on the pasture plus the adjacent milking periods).

The average $\mathrm{CH}_{4}$ emissions of the soil and the cow emissions were derived by EC measurements as mentioned in Sect. 2.3.2 and allocated to the respective time periods.

Emissions of $\mathrm{N}_{2} \mathrm{O}$ in terms of $\mathrm{N}$ mass were estimated according to

$$
\begin{gathered}
F_{\mathrm{N}-\mathrm{N}_{2} \mathrm{O}}=\left(F_{\mathrm{N} \text {-fertil }}+F_{\mathrm{N} \text {-resid }}+F_{\mathrm{N} \text {-dep }}\right) \\
\cdot f_{1}+F_{\mathrm{N} \text {-excreta }} \cdot f_{2},
\end{gathered}
$$

where $F_{\mathrm{N} \text {-fertil }}, F_{\mathrm{N} \text {-resid }}$ and $F_{\mathrm{N} \text {-dep }}$ are the $\mathrm{N}$ inputs by fertilizers, plant residues, and atmospheric deposition, and $f_{1}=0.01$ and $f_{2}=0.02$ are the default $\mathrm{N}_{2} \mathrm{O}$ emission factors due to the respective $\mathrm{N}$ inputs according to the IPCC

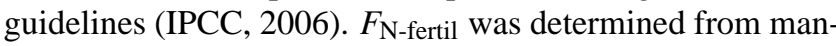




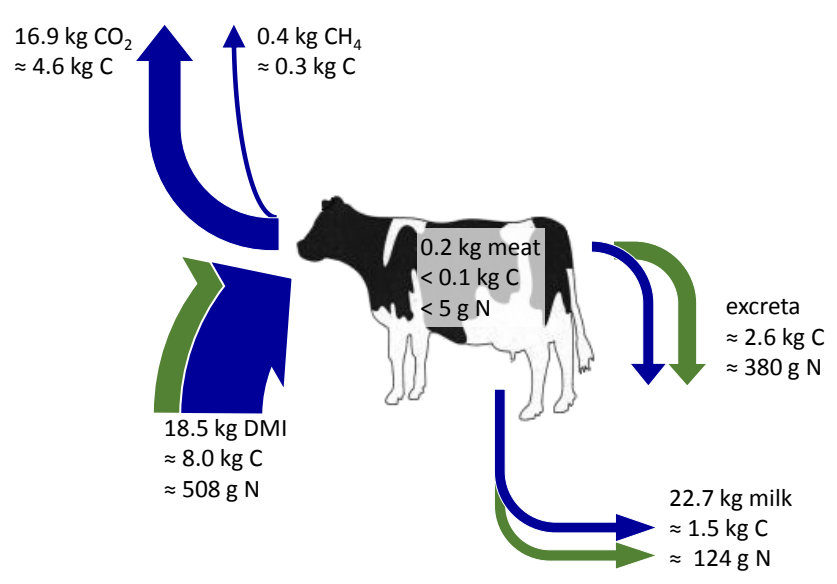

Figure 3. Average daily carbon (blue arrows) and nitrogen (green arrows) budget of the studied dairy cows. The budget was closed by adjusting the amount of excreta loss.

agement records and the analysis of the applied slurry (see Sect. 2.3.3) and amounted to $120 \mathrm{~kg} \mathrm{Nha}^{-1}$ in total for the study year. The amount of $\mathrm{N}$ deposited from the atmosphere was estimated to be $25 \mathrm{~kg} \mathrm{Nha}^{-1} \mathrm{yr}^{-1}$ based on the report of the Swiss Federal Commission for Air Hygiene (FCAH, 2014).

The other two terms in Eq. (8), were estimated with the help of the animal $\mathrm{N}$ balance, which can be formulated in a similar way as the animal carbon balance in Eq. (5) but without gaseous pathways:

$E_{\mathrm{N} \text {-intake }}=E_{\mathrm{N} \text {-milk }}+E_{\mathrm{N} \text {-meat }}+E_{\mathrm{N} \text {-excreta }}$.

$E_{\mathrm{N} \text {-intake }}$ is the uptake of $\mathrm{N}$ in the feed and the average value was quantified based on the average $\mathrm{N}$ content of pasture forage $\left(28 \mathrm{~g} \mathrm{~N}(\mathrm{~kg} \mathrm{DM})^{-1}\right)$ and concentrates $(17 \mathrm{~g} \mathrm{~N}$ $\left.(\mathrm{kg} \mathrm{DM})^{-1}\right)$. The intake of the cow is portioned into $\mathrm{N}$ in milk $\left(E_{\mathrm{N} \text {-milk }}\right)$, live weight gain $\left(E_{\mathrm{N} \text {-meat }}\right)$, and excreta $\left(E_{\mathrm{N} \text {-excreta }}\right)$. Average milk $\mathrm{N}$ output $\left(E_{\mathrm{N} \text {-milk }}\right)$ was determined from the mean ECM yield $\left(22.7 \mathrm{~kg} \mathrm{head}^{-1} \mathrm{~d}^{-1}\right)$ and associated measured protein contents ranging from 2.8 to $4.5 \%$ and a protein-to-N conversion factor of 6.38 (IPCC, 2006). Nitrogen accumulation in meat due to weight gain (see e.g., Estermann et al., 2002) was very small and thus assumed negligible (like for C, see Sect. 2.4.1). $E_{\mathrm{N} \text {-excreta was estimated }}$ by closing the $\mathrm{N}$ balance (Eq. 8) and was used to calculate $F_{\mathrm{N} \text {-excreta }}$ in analogy to Eq. (4) for the effective pasture time resulting in a value of $152 \mathrm{~kg} \mathrm{~N} \mathrm{ha}^{-1} \mathrm{yr}^{-1}$.

Nitrogen input from plant residues $F_{\mathrm{N} \text {-resid }}=51 \mathrm{~kg} \mathrm{Nha}^{-1} \mathrm{yr}^{-1}$ was estimated as $25 \%$ of the livestock $\mathrm{N}$ intake during the grazing period based on Walther et al. (1994) and AGRIDEA (2007).

\section{Results and discussion}

\subsection{Carbon budget of the dairy cows}

Animal $\mathrm{C}$ budget considerations serve to estimate, constrain or validate animal-related $\mathrm{C}$ fluxes that contribute to the pasture system NECB. Results derived for the mean daily C budget for the cows used in this study are shown in Fig. 3 together with the $\mathrm{N}$ budget (detailed numbers can be found in Table S1). The values represent averages over all cows in the herd and over the entire grazing season. The average cow needed a daily feed intake of $18.5 \mathrm{~kg}$ DM corresponding to $8.0 \mathrm{~kg} \mathrm{C}$. The determination of the feed intake was a very important factor for the assessment of the cow budget. Because in situ determination of forage intake during grazing is challenging (Undi et al., 2008), the total feed intake was calculated based on the net energy requirements of the animals, which in turn were based on the actual animal performance (milk yield, live weight). The applied models (Sect. 2.4.2) showed only a small difference of $0.3 \mathrm{~kg} \mathrm{DM} \mathrm{head}^{-1} \mathrm{~d}^{-1}$. Gibb et al. (2007) reported intake values for grazing dairy cows between 25 and $30 \mathrm{gDM}(\mathrm{kg} \mathrm{LW})^{-1}$. For the live weight of the cows in this study, this would result in intake rates of 16 and $18 \mathrm{~kg} \mathrm{DM} \mathrm{head}^{-1} \mathrm{~d}^{-1}$, which is within the estimated uncertainty range $\left( \pm 2.7 \mathrm{~kg} \mathrm{DM} \mathrm{head}^{-1} \mathrm{~d}^{-1}\right)$ of our result.

Of the total $\mathrm{C}$ intake the largest share $(57 \%)$ was emitted as $\mathrm{CO}_{2}$ and a much smaller part $(4 \%)$ as $\mathrm{CH}_{4}$. A considerable amount $(19 \%)$ of the $\mathrm{C}$ intake was processed into the milk and $32 \%$ was released as excreta. The animal carbon budget shows an imbalance of $12 \%$ (see Table S1), which reflects the overall budget uncertainty. Most of $\mathrm{C}$ was lost by respiration, which also has the largest uncertainty. The value was determined from EC measurements and was found to be at the upper range of animal respiration rates for dairy cows reported in the literature (see Felber et al., 2016 and references therein). In contrast to the carbon budget, the largest part of the $\mathrm{N}$ intake $(75 \%)$ was excreted in urine and dung.

The relative share of excreta $\mathrm{C}$ loss is very similar to the $34 \%$ share in terms of DM reported by Woodward et al. (2012) for dairy cows. The resulting imbalance of the animal budget, although within the range of uncertainties, may indicate that the estimated $\mathrm{C}$ loss due to respiration tends to be overestimated. Indeed the value of $4.6 \mathrm{kgChead}^{-1} \mathrm{~d}^{-1}$ lies in the upper range of measurements with comparable cows (see Felber et al., 2016). However, Soussana et al. (2010) investigating cow $\mathrm{C}$ budgets for cut forage, which was fed off-pasture, found that 56 to $59 \%$ of intake $\mathrm{C}$ was respired as $\mathrm{CO}_{2}$.

\subsection{Carbon budget of the pasture system}

Carbon budget components and balance results for the two different NECB approaches (system boundaries) used in this study are shown in Fig. 4 (detailed numbers are listed in 


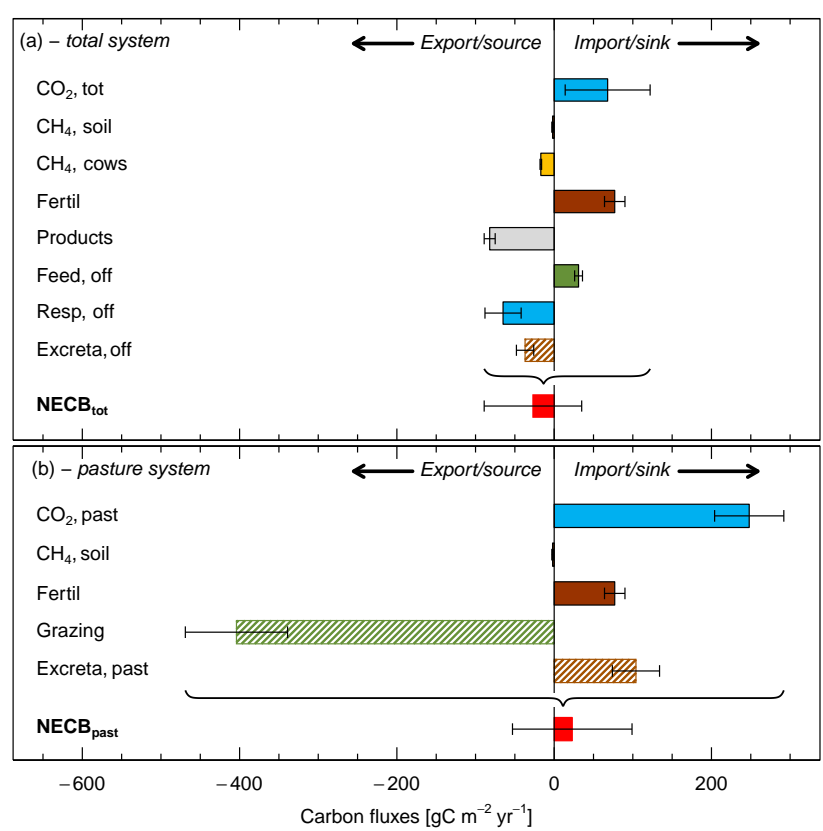

Figure 4. Components and uncertainties (95\% confidence range) of annual carbon budget determined with (a) the total system and (b) the pasture system approach as illustrated in Fig. 3. NECB was calculated according to Eqs. (2) and (3). Flux direction is defined according to ecological sign convention: positive values indicate imports to the system, negative values indicate export (loss) from the system. Filled bars indicate values derived from direct measurements, hatched bars indicate values that are modeled with measured and modeled data.

Table S2). While for $\mathrm{NECB}_{\text {tot }}$ a small negative and for $\mathrm{NECB}_{\text {past }}$ a small positive value was determined, both results are attributed to a considerable uncertainty range and are thus not significantly different from zero nor from each other. $\mathrm{NECB}_{\text {past }}$ with the larger uncertainty also resulted from larger budget components (fluxes). A total $\mathrm{C}$ import of $429 \mathrm{~g} \mathrm{C} \mathrm{m}^{-2} \mathrm{yr}^{-1}$ to the pasture (soil/vegetation ecosystem) was balanced by a total C loss of $-406 \mathrm{~g} \mathrm{C} \mathrm{m}^{-2} \mathrm{yr}^{-1}$. For the $\mathrm{NECB}_{\text {tot }}$ approach, total import $\left(176 \mathrm{~g} \mathrm{C} \mathrm{m}^{-2} \mathrm{yr}^{-1}\right)$ and total export $\left(-202 \mathrm{~g} \mathrm{C} \mathrm{m}^{-2} \mathrm{yr}^{-1}\right)$ were less than half as large (it has to be noted that in this consideration the annual net $\mathrm{CO}_{2}$ exchange is used, not the gross exchange). This difference is due to the predominantly "internal" processing of the biomass in the $\mathrm{NECB}_{\text {tot }}$ system. Accordingly, the largest budget term in the $\mathrm{NECB}_{\text {tot }}$ approach was the milk export $\left(F_{\mathrm{C} \text {-products }}=-82 \mathrm{~g} \mathrm{C} \mathrm{m}^{-2} \mathrm{yr}^{-1}\right)$, while the largest term in the $\mathrm{NECB}_{\text {past }}$ approach, the biomass export by grazing $\left(F_{\mathrm{C} \text {-grazing }}=-404 \mathrm{~g} \mathrm{C} \mathrm{m}^{-2} \mathrm{yr}^{-1}\right)$, was five times larger. Additionally, combining the $\mathrm{C}$ lost as respired $\mathrm{CO}_{2}$ when the cows were off-pasture and the net $\mathrm{C}$ imported as $\mathrm{CO}_{2}$ into the system resulted in a zero-sum situation for the $\mathrm{CO}_{2}$ exchange in the $\mathrm{NECB}_{\text {tot }}$ approach, but was the main contributor to the $\mathrm{NECB}_{\text {tot }}$ uncertainty. As discussed in detail in Felber et al. (2016), the difference in the net $\mathrm{CO}_{2}$ exchange between the two approaches corresponds to the (annually averaged) effect of cow respiration while on the pasture. Although this annual cow respiration flux $\left(180 \mathrm{~g} \mathrm{C} \mathrm{m}^{-2} \mathrm{yr}^{-1}\right)$ is typically much lower than the respiration of the pasture soil/vegetation (Jérôme et al., 2014), it is larger than many other carbon budget terms and thus very important for the NECB quantification.

The time that the cows spent each day in the barn for milking represents an important "disturbance" of the $\mathrm{NECB}_{\text {tot }}$. The sum of the three specific off-pasture fluxes $\left(F_{\mathrm{C} \text {-feed,off }}\right.$, $\left.F_{\mathrm{C} \text {-resp,off }}, F_{\mathrm{C} \text {-excreta,off }}\right)$ results in a net off-pasture carbon loss of $-71 \mathrm{~g} \mathrm{C} \mathrm{m}^{-2} \mathrm{yr}^{-1}$. The relatively small $\mathrm{C}$ import due to concentrate feeding only partially balanced the loss through animal respiration and excreta.

While the resulting NECB values for a single year cannot be considered as fully representative for the site nor for pasture systems in general, they show the contribution of different $\mathrm{C}$ fluxes to the total budget and the effect of their (propagated) uncertainty in an exemplary way. As shown in Fig. 4, the resulting uncertainty of $\mathrm{NECB}_{\text {past }}\left( \pm 76 \mathrm{~g} \mathrm{C} \mathrm{m}^{-2} \mathrm{yr}^{-1}\right)$ was larger than for $\mathrm{NECB}_{\text {tot }}\left( \pm 62 \mathrm{~g} \mathrm{C} \mathrm{m}^{-2} \mathrm{yr}^{-1}\right)$. These uncertainties are comparable to the uncertainty ranges reported by Rutledge et al. (2015) for annual $\mathrm{NECB}_{\text {tot }}$ values of a dairy pasture system $\left( \pm 50\right.$ to $\left.\pm 86 \mathrm{~g} \mathrm{C} \mathrm{m}^{-2} \mathrm{yr}^{-1}\right)$. It may be argued that the larger absolute uncertainty of $\mathrm{NECB}_{\text {past }}$ compared to $\mathrm{NECB}_{\text {tot }}$ was due to the larger individual $\mathrm{C}$ fluxes in this approach. This mainly applies to the largest flux $F_{\mathrm{C} \text {-grazing }}$ that dominated the $\mathrm{NECB}_{\text {past }}$ uncertainty. The grazing intake was inferred using an empirical model based on measured milk yield, composition and animal live weight. The model uncertainty is also the main contributor to the uncertainty of $F_{\mathrm{C} \text {-grazing }}$ (see Sect. S1.1). However, direct intake measurements on the pasture are difficult and would probably not yield more accurate results.

The largest uncertainty contribution in the $\mathrm{NECB}_{\text {tot }}$ approach was due to the $\mathrm{CO}_{2}$ exchange flux, although the magnitude of this term was not very large. The uncertainty of $F_{\mathrm{C}-\mathrm{CO}_{2}}$ was mainly determined by the gaps in the $\mathrm{CO}_{2}$ flux measurement and although the calculation of $F_{\mathrm{C}-\mathrm{CO}_{2} \text {,tot is }}$

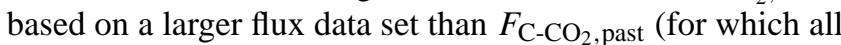
fluxes influenced by cows were removed before gap filling) the former had a larger uncertainty (for details see Felber et al., 2016). The uncertainty of the annual $\mathrm{CO}_{2}$ exchange has an absolute rather than a relative characteristic because, like the NECB, it is itself the result of large compensating fluxes of opposite signs (Ammann et al., 2009; Felber et al., 2016).

Another important component in both NECB approaches was the $\mathrm{C}$ import by slurry application, which was also shown for other managed grasslands (Ammann et al., 2007; Soussana et al., 2007). Only by specific sampling and analysis of the applied slurry, the relative error could be limited to $<20 \%$, because the DM and thus also the C content in slurry can easily vary by a factor of four.

Carbon lost as $\mathrm{CH}_{4}$ from the soil was the lowest flux in both systems accounting for less than $1 \%$ of total $\mathrm{C}$ loss. 


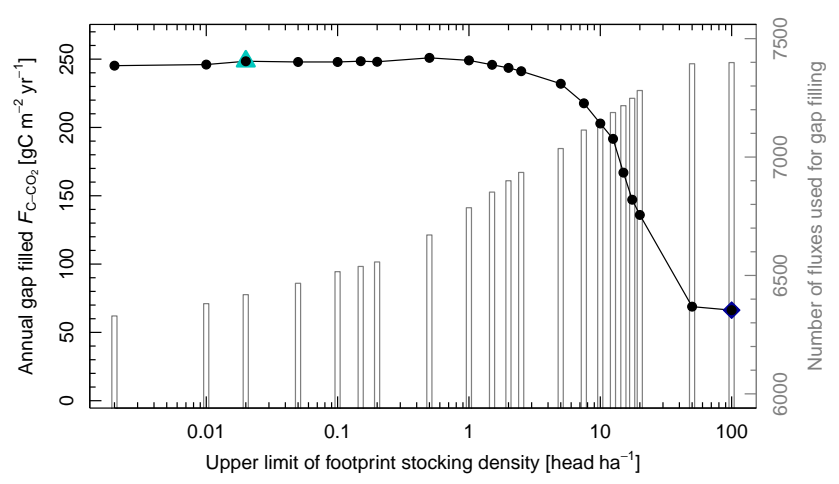

Figure 5. Effect of $\mathrm{CO}_{2}$ flux selection based on the observed cow stocking density within the flux footprint on the annual $\mathrm{CO}_{2}$ exchange $\left(F_{\mathrm{C}-\mathrm{CO}_{2}}=-\mathrm{NEE}\right)$ and number of fluxes used for the gap filling (bars). The dark blue diamond symbol represents $F_{\mathrm{C}-\mathrm{CO}_{2} \text {,tot }}$, the light blue triangle represents $F_{\mathrm{C}-\mathrm{CO}_{2} \text {,past }}$.

While this term appears to be negligible, this is not the case for the animal $\mathrm{CH}_{4}$ emission $\left(F_{\mathrm{C}-\mathrm{CH}_{4} \text {,cows }}\right)$ with a contribution of $8 \%$ to the total $\mathrm{C}$ loss in the $\mathrm{NECB}_{\text {tot }}$ system. In any case the $\mathrm{CH}_{4}$ fluxes play a much more prominent role when compared to other GHG fluxes in terms of global warming potential (cf. Sect. 3.4).

Beside the quality and representativeness of the determination of the various $C$ fluxes, the completeness of the budget with all relevant components is also important. In the present study, the loss of $\mathrm{C}$ through leaching and erosion was not measured, but assumed to be small compared to the other $\mathrm{C}$ fluxes. Carbon loss through leaching in other managed grasslands was found to be in the range of 5 to $11 \mathrm{~g} \mathrm{C} \mathrm{m}^{-2} \mathrm{yr}^{-1}$ (Allard et al., 2007; Zeeman et al., 2010; Rutledge et al., 2015). The loss through erosion can be assumed to be again smaller due to the flat topography and the closed vegetation cover in this study. Even if a value for leaching and erosion in the order of $10 \mathrm{~g} \mathrm{C} \mathrm{m}^{-2} \mathrm{yr}^{-1}$ were to be included in the budget calculation, the result of the budgets would hardly be affected (i.e., the NECB values would remain non-significant).

\subsection{Applicability of the NECB approaches}

The applicability of the two different NECB approaches depends on their specific requirements and the corresponding available information for the investigated pasture system. For the $\mathrm{NECB}_{\text {past }}$ approach the adequate determination of the relatively large $\mathrm{CO}_{2}$ exchange flux relies on the capability to distinguish between measurement intervals with and without cow influence.

In the present study, GPS position information of the cows in combination with a flux footprint model allowed an explicit distinction of fluxes with and without cow contributions and a detailed determination of times when the cows were on- or off-pasture. The separation of $\mathrm{CO}_{2}\left(\right.$ and $\left.\mathrm{CH}_{4}\right)$ fluxes was achieved based on the actual stocking density in the flux footprint (for details see Felber et al., 2015). The effect of the chosen threshold for this separation on the resulting annual net $\mathrm{CO}_{2}$ exchange is illustrated in Fig. 5. Above an average stocking rate of about 3 heads ha ${ }^{-1}$ in the footprint the cow respiration led to a strong change of the net $\mathrm{CO}_{2}$ exchange, although these cases accounted for only about $5 \%$ of all flux data (before gap filling).

The required degree of detail of the position information depends on the grazing management, stocking density and division of the pasture around the measurement tower. Felber et al. (2015) showed that information of paddock occupation and the assumption of homogeneously distributed cows within the paddock resulted in comparable results of cow $\mathrm{CH}_{4}$ emission estimates for the division used in this experiment. For pasture systems with a distinct alternation of grazing and non-grazing phases (e.g., Jérôme et al., 2014) a simple time schedule based flux separation, without further animal position information, may also be sufficient, but needs to be tested. However, for a free-range (continuous grazing) pasture system where the cows are allowed to graze all around the measurement tower at all times, the $\mathrm{NECB}_{\text {past }}$ approach would not be feasible; pasture/soil $\mathrm{CO}_{2}$ and $\mathrm{CH}_{4} \mathrm{ex}$ change $\left(F_{\mathrm{C}-\mathrm{CO}_{2} \text {,past }}\right.$ and $\left.F_{\mathrm{C}-\mathrm{CH}_{4} \text {, soil }}\right)$ can only be determined if sufficient and defined periods without cow influence on the EC flux measurement are available.

While the $\mathrm{NECB}_{\text {past }}$ approach necessitates a proper identification of pasture $\mathrm{CO}_{2}$ fluxes without cow respiration, it does not rely on off-pasture information. However, the import and export of $\mathrm{C}$ in excreta and forage needs to be determined. Thus the $\mathrm{NECB}_{\text {past }}$ approach may be suitable for systems with known animal performance and/or short intensive grazing phases, for which the grazing export can be well constrained. The $\mathrm{NECB}_{\text {past }}$ approach is also suitable for grassland systems with mixed management (grazing and harvest), because the harvest export can be treated in the same way as grazing export (Skinner, 2008).

The $\mathrm{NECB}_{\text {tot }}$ approach is more suitable (or even the only choice) for continuous grazing systems (e.g., Allard et al., 2007). For beef cattle pastures, the $\mathrm{NECB}_{\text {tot }}$ approach can even be simplified, because the off-pasture phases are avoidable. While a separation of the fluxes influenced by cow respiration is not necessary in this approach, it needs to be assured that cow respiration contributions are fully represented in $\mathrm{NECB}_{\text {tot }}$, i.e. that the cows show a temporally representative presence in the flux footprint (see Felber et al., 2015).

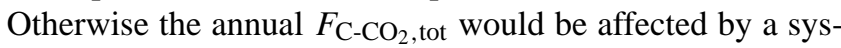
tematic error as also noted by Kirschbaum et al. (2015).

Generally, for any pasture system it is advisable to record as detailed information of non-gaseous $\mathrm{C}$ fluxes, cow positions, and grazing time schedules as possible, because the simultaneous application of both approaches and their intercomparison provides the most defensible results for the $\mathrm{C}$ budget. Because the two NECB approaches partly include the same fluxes (e.g., $\left.F_{\mathrm{C} \text {-fertil }}\right)$ or are based on the same information (e.g., $F_{\mathrm{C} \text {-excreta,past }}$ and $F_{\mathrm{C} \text {-excreta,off }}$ ) they cannot 


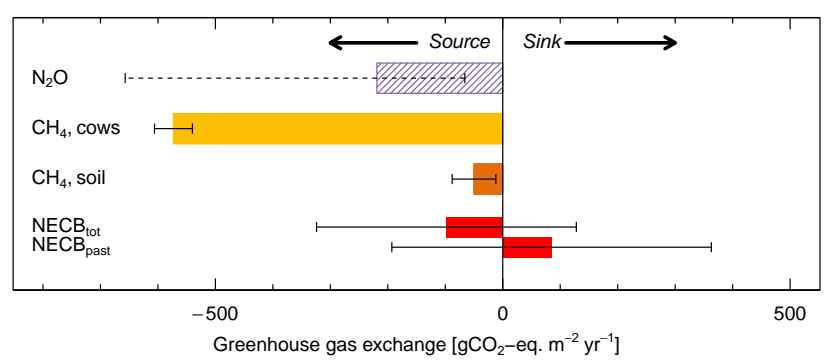

Figure 6. Comparison of greenhouse gas fluxes of the pasture system including cows during pasture use to the NECBs for the two system boundaries. The ecological sign convention is used: negative values indicate a source from the system to the atmosphere. $\mathrm{N}_{2} \mathrm{O}$ emissions are modeled, whereas the other emissions are measurements. Detailed numbers can be found in Table S3.

be considered as totally independent. However, the dominant contributions and their uncertainties may be considered as statistically independent.

\subsection{Comparison to other greenhouse gas fluxes of the dairy cow pasture}

The NECB results are compared to the effect of other GHG fluxes for the investigated pasture system in Fig. 6. In terms of $\mathrm{CO}_{2}$ equivalents, the $\mathrm{CH}_{4}$ emissions from the animals contributed the most to GHG emissions, while the $\mathrm{CH}_{4}$ emission from soil (including animal excreta) was 10 times lower but not negligible. $\mathrm{N}_{2} \mathrm{O}$ emissions contributed about one fourth to the total emissions. Due to the non-significant effect of the C storage change (near neutral NECB) this grazing system may not be considered as a $\mathrm{C}$ sink and thus a mitigation option for GHG emissions as suggested by other studies (Soussana et al., 2010; Rutledge et al., 2015).

However, for a reliable assessment of the $\mathrm{C}$ budget of a pasture, measurements over several years are crucial. Environmental as well as management factors will have a large influence on the annual budget and determine whether a system acts as a $\mathrm{C}$ sink or a source. For example, plowing during restoration process of a pasture can lead to a considerable loss of $\mathrm{C}$ that was sequestered over several years, also affecting $\mathrm{N}_{2} \mathrm{O}$ emissions (Ammann et al., 2013; Merbold et al., 2014).

In contrast to NECB and $\mathrm{CH}_{4}$ emissions, which were determined experimentally using the EC method, $\mathrm{N}_{2} \mathrm{O}$ emissions were roughly estimated here based on modeled $\mathrm{N}$ cycling of the cows and applied fertilizers relying on standardized emission factors. A more comprehensive picture, accounting for the specific environmental conditions, could be achieved by the direct determination of $\mathrm{N}_{2} \mathrm{O}$ fluxes also using the EC method. Such measurements will be performed in a follow-up project investigating the $\mathrm{N}$ cycling of the same pasture (NiceGras: Nitrogen Cycling and Emissions of Grazing Systems).

\section{Conclusions}

The $\mathrm{C}$ storage change of a grazed pasture system was determined by two NECB approaches with different system boundaries to investigate their data requirements and associated uncertainties. While both approaches yielded similar results indicating a near carbon-neutral budget, both methods resulted in considerable uncertainties, with slightly lower uncertainties for the $\mathrm{NECB}_{\text {tot }}$ approach (system boundaries including cows). Whereas the $\mathrm{C}$ budget results for the investigated single year cannot be considered as fully representative for the longer term, they demonstrate the contribution of the different $\mathrm{C}$ fluxes to the total budget and the effect of their (propagated) uncertainty in an exemplary way. The simultaneous application and comparison of both NECB approaches provides a useful consistency check for the NECB determination and can help to identify and eliminate larger systematic errors. Additionally, the consideration of the cow $\mathrm{C}$ budget can be used to quantify and check the consistency of animal fluxes needed in the determination of the NECB.

The NECB result was compared to the effect of the other GHG fluxes from the pasture system $\left(\mathrm{CH}_{4}\right.$ and $\mathrm{N}_{2} \mathrm{O}$ normalized to $\mathrm{CO}_{2}$ equivalents). While $\mathrm{CH}_{4}$ emission by the cows played a very minor role in the $\mathrm{C}$ budget, it clearly dominates the GHG emissions due to its larger greenhouse warming potential. Due to its relatively low variability the $\mathrm{CH}_{4}$ emission from enteric fermentation (depending on animal state and performance) has a much lower uncertainty than the NECB of the pasture field, which is the net effect of large fluxes of opposite sign.

While the determination of the non-gaseous fluxes in the $\mathrm{C}$ budget could mostly be improved by more comprehensive sampling and analyses, the uncertainty due to the $\mathrm{CO}_{2}$ exchange measurements is to a certain part inevitable for the given site and management regime, because the accuracy of the $\mathrm{CO}_{2}$ exchange monitoring by eddy covariance is limited by the (micro-) meteorological conditions, especially calm nighttime conditions, and by the variability of the animal presence and density in the footprint. However, the uncertainty may be reduced to some degree by better constrained animal $\mathrm{C}$ budgets (especially intake and respiration). This may be achieved by prolonged field measurements over several years in combination with $\mathrm{C}$ cycling measurements on the individual animals.

\section{The Supplement related to this article is available online at doi:10.5194/bg-13-2959-2016-supplement.}

Acknowledgements. We gratefully acknowledge the funding from the Swiss National Science Foundation (Grant no. 205321_138300) and the EU-FP7 Project ECLAIRE. We wish to thank Hubert Bollhalder, Roman Gubler, Veronika Wolff, 
Andreas Rohner, Manuel Schuler, Markus Jocher, Manuela Falk, Lukas Eggerschwiler and Bernard Papaux for support with the sensors and in the field.

Edited by: A. Ito

\section{References}

AGRIDEA: Pflanzen und Tiere 2008: Wirz Handbuch, AGRIDEA Lindau/Wirz Verlag, Lindau/Basel, Switzerland, 2007.

Allard, V., Soussana, J.-F., Falcimagne, R., Berbigier, P., Bonnefond, J. M., Ceschia, E., D’hour, P., Hénault, C., Laville, P., Martin, C., and Pinarès-Patino, C.: The role of grazing management for the net biome productivity and greenhouse gas budget $\left(\mathrm{CO}_{2}\right.$, $\mathrm{N}_{2} \mathrm{O}$ and $\mathrm{CH}_{4}$ ) of semi-natural grassland, Agr. Ecosyst. Environ., 121, 47-58, doi:10.1016/j.agee.2006.12.004, 2007.

Ammann, C., Flechard, C. R., Leifeld, J., Neftel, A., and Fuhrer, J.: The carbon budget of newly established temperate grassland depends on management intensity, Agr. Ecosyst. Environ., 121, 5-20, doi:10.1016/j.agee.2006.12.002, 2007.

Ammann, C., Spirig, C., Leifeld, J., and Neftel, A.: Assessment of the nitrogen and carbon budget of two managed temperate grassland fields, Agr. Ecosyst. Environ., 133, 150-162, doi:10.1016/j.agee.2009.05.006, 2009.

Ammann, C., Leifeld, J., Jocher, M., Neftel, A., and Fuhrer, J.: Effect of grassland renovation on the greenhouse gas budget of an intensive forage production system, in Advances in Animal Biosciences, Cambridge University Press, Dublin, Ireland, 2326 June 2013, 4, 284 pp., 2013.

Arrigo, Y., Chaubert, C., Daccord, R., Gagnaux, D., Gerber, H., Guidon, D., Jans, F., Kessler, J., Lehmann, E., Morel, I., Münger, A., Rouel, M., and Wyss, U.: Fütterungsempfehlungen und Nährwerttabellen für Wiederkäuer: das grüne Buch, 4th Edn., Eidgenössische Forschungsanstalt für Nutztiere, Zollikofen, Switzerland, 1999.

Avila, R.: The ecosystem models used for dose assessments in SRCan, Swedish Nuclear Fuel and Waste Management Co., Stockholm, Sweden, available at: http://www.iaea.org/inis/collection/ NCLCollectionStore/_Public/38/021/38021344.pdf (last access: 3 June 2015), 2006.

Chapin, F. S., Woodwell, G. M., Randerson, J. T., Rastetter, E. B., Lovett, G. M., Baldocchi, D. D., Clark, D. A., Harmon, M. E., Schimel, D. S., Valentini, R., Wirth, C., Aber, J. D., Cole, J. J., Goulden, M. L., Harden, J. W., Heimann, M., Howarth, R. W., Matson, P. A., McGuire, A. D., Melillo, J. M., Mooney, H. A., Neff, J. C., Houghton, R. A., Pace, M. L., Ryan, M. G., Running, S. W., Sala, O. E., Schlesinger, W. H., and Schulze, E.-D.: Reconciling Carbon-cycle Concepts, Terminology, and Methods, Ecosystems, 9, 1041-1050, doi:10.1007/s10021-005-01057, 2006.

Estermann, B. L., Wettstein, H.-R., Sutter, F., and Kreuzer, M.: Nutrient and energy conversion of grass-fed dairy and suckler beef cattle kept indoors and on high altitude pasture, Anim. Res., 50, 477-494, doi:10.1051/animres:2001109, 2002.

FCAH: Ammoniak-Immissionen und Stickstoffeinträge (Ammonia Immissions and Nitrogen Imports), Federal Commission for Air Hygiene (FCAH), Bern, Switzerland, 2014.
Felber, R., Münger, A., Neftel, A., and Ammann, C.: Eddy covariance methane flux measurements over a grazed pasture: effect of cows as moving point sources, Biogeosciences, 12, 3925-3940, doi:10.5194/bg-12-3925-2015, 2015.

Felber, R., Neftel, A., and Ammann, C.: Discerning the cows from the pasture: Quantifying and partitioning the NEE of a grazed pasture using animal position data, Agric. For. Meteorol., 216, 37-47, doi:10.1016/j.agrformet.2015.09.018, 2016.

Gibb, M.: Grassland management with emphasis on grazing behaviour, in: Fresh herbage for dairy cattle: the key to a sustainable food chain, edited by: Elgersma, A., Dijkstra, J., and Tamminga, S., 141-157, Springer Publishing, Dordrecht, Netherlands, available at: http://library.wur.nl/ojs/index. php/frontis/article/view/1250 (last access: 22 April 2015), 2007.

IPCC: 2006 IPCC Guidelines for National Greenhouse Gas Inventories, vol. 4 Ariculture, Forestry and Other Land Use, Intergovernmental Panel on Climate Change, Hayma, Japan, available at: http://www.ipcc-nggip.iges.or.jp/public/2006gl/index. htm (last access: 31 March 2015), 2006.

IPCC: Climate Change 2014: Synthesis Report, Contribution of Working Groups I, II and III to the Fifth Assessment Report of the Intergovernmental Panel on Climate Change, Core Writing Team, edited by: Pachauri, R. K. and Meyer, L. A., Intergovernmental Panel on Climate Change, Geneva, Switzerland, 2014.

Jérôme, E., Beckers, Y., Bodson, B., Heinesch, B., Moureaux, C., and Aubinet, M.: Impact of grazing on carbon dioxide exchanges in an intensively managed Belgian grassland, Agr. Ecosyst. Environ., 194, 7-16, doi:10.1016/j.agee.2014.04.021, 2014.

Kirschbaum, M. U. F., Rutledge, S., Kuijper, I. A., Mudge, P. L., Puche, N., Wall, A. M., Roach, C. G., Schipper, L. A., and Campbell, D. I.: Modelling carbon and water exchange of a grazed pasture in New Zealand constrained by eddy covariance measurements, Sci. Total Environ., 512-513, 273-286, doi:10.1016/j.scitotenv.2015.01.045, 2015.

Merbold, L., Eugster, W., Stieger, J., Zahniser, M., Nelson, D., and Buchmann, N.: Greenhouse gas budget $\left(\mathrm{CO}_{2}, \mathrm{CH}_{4}\right.$ and $\left.\mathrm{N}_{2} \mathrm{O}\right)$ of intensively managed grassland following restoration, Glob. Change Biol., 20, 1913-1928, doi:10.1111/gcb.12518, 2014.

MeteoSchweiz: Climate normals Fribourg/Posieux, available at: http://www. meteoschweiz.admin.ch/product/output/climate-data/ climate-diagrams-normal-values-station-processing/GRA/ climsheet_GRA_np8110_e.pdf, last access: 17 May 2016.

Mudge, P. L., Wallace, D. F., Rutledge, S., Campbell, D. I., Schipper, L. A., and Hosking, C. L.: Carbon balance of an intensively grazed temperate pasture in two climatically contrasting years, Agr. Ecosyst. Environ., 144, 271-280, doi:10.1016/j.agee.2011.09.003, 2011.

Pettygrove, G. S., Heinrich, A. L., and Eagle, A. J.: Dairy manure nutrient content and forms, University of California Manure Technical Guide Series for Crop Management Professionals, available at: http://manuremanagement.ucdavis.edu/ files/134369.pdf (last accessed 17 May 2016), 2010.

Rutledge, S., Mudge, P. L., Campbell, D. I., Woodward, S. L., Goodrich, J. P., Wall, A. M., Kirschbaum, M. U. F., and Schipper, L. A.: Carbon balance of an intensively grazed temperate dairy pasture over four years, Agr. Ecosyst. Environ., 206, 1020, doi:10.1016/j.agee.2015.03.011, 2015. 
Skinner, R. H.: High Biomass Removal Limits Carbon Sequestration Potential of Mature Temperate Pastures, J. Environ. Qual., 37, 1319-1326, doi:10.2134/jeq2007.0263, 2008.

Smith, P.: How long before a change in soil organic carbon can be detected?, Glob. Change Biol., 10, 1878-1883, doi:10.1111/j.1365-2486.2004.00854.x, 2004.

Solomon, S., Qin, D., Manning, M., Chen, Z., Marquis, M., Averyt, K. B., Tignor, M., and Miller, H. L.: Climate Change 2007: The Physical Science Basis., Contribution of Working Group I to the Fourth Assessment Report of the Intergovernmental Panel on Climate Change, Cambridge University Press, Cambridge, United Kingdom and New York, NY, USA, available at: https://www.ipcc.ch/publications_and_data/ar4/wg1/en/ spm.html (last access: 23 May 2015), 2007.

Soussana, J. F., Allard, V., Pilegaard, K., Ambus, P., Amman, C., Campbell, C., Ceschia, E., Clifton-Brown, J., Czobel, S., Domingues, R., Flechard, C., Fuhrer, J., Hensen, A., Horvath, L., Jones, M., Kasper, G., Martin, C., Nagy, Z., Neftel, A., Raschi, A., Baronti, S., Rees, R. M., Skiba, U., Stefani, P., Manca, G., Sutton, M., Tuba, Z., and Valentini, R.: Full accounting of the greenhouse gas $\left(\mathrm{CO}_{2}, \mathrm{~N}_{2} \mathrm{O}, \mathrm{CH}_{4}\right)$ budget of nine European grassland sites, Agr. Ecosyst. Environ., 121, 121-134, doi:10.1016/j.agee.2006.12.022, 2007.

Soussana, J. F., Tallec, T., and Blanfort, V.: Mitigating the greenhouse gas balance of ruminant production systems through carbon sequestration in grasslands, Animal, 4, 334-350, doi:10.1017/S1751731109990784, 2010.

Tilley, J. M. A. and Terry, R. A.: A two-stage technique for the in vitro digestion of forage crops, Grass Forage Sci., 18, 104-111, doi:10.1111/j.1365-2494.1963.tb00335.x, 1963.

Tubiello, F. N., Salvatore, M., Ferrara, A. F., House, J., Federici, S., Rossi, S., Biancalani, R., Condor Golec, R. D., Jacobs, H., Flammini, A., Prosperi, P., Cardenas-Galindo, P., Schmidhuber, J., Sanz Sanchez, M. J., Srivastava, N., and Smith, P.: The Contribution of Agriculture, Forestry and other Land Use activities to Global Warming, 1990-2012, Glob. Change Biol., 21, 26552660, doi:10.1111/gcb.12865, 2015.
Undi, M., Wilson, C., Ominski, K. H., and Wittenberg, M.: Comparison of techniques for estimation of forage dry matter intake by grazing beef cattle, Can. J. Soil Sci., 88, 693-701, doi:10.4141/CJAS08041, 2008.

UNFCCC: Synthesis and Assessment Report on the Greenhouse Gas Inventories Submitted in 2014, United Nations Framework Convention on Climate Change, Bonn, Germany, available at: http://www.ccrasa.com/library_1/12491 - UNFCCC - Synthesis and assessment report on the green (last access: 11 June 2015), 2014.

VDLUFA: Die Untersuchung von Sekundärrohstoffdüngern, Kultursubstraten und Bodenhilfsstoffen, Verband Deutscher Landwirtschaftlicher Untersuchungs- und Forschungsanstalten, VDLUFA-Verlag, 204 pp., Speyer, 2000.

Walther, U., Menzi, H., Ryser, J.-P., Flisch, R., Jeangros, B., Maillard, A., and Vuilloud, P. A.: Grundlagen für die Düngung im Acker- und Futterbau, Agrarforschung, 1, 1-40, 1994.

Woodward, S. L., Waghorn, G. C., Bryant, M. A., and Benton, A.: Can diverse pasture mixtures reduce nitrogen losses?, in: Proceedings of the 5th Australian Dairy Science Symposium, edited by: Jacobs, J., Melbourne, Australia, 463-464, 2012.

Zeeman, M. J., Hiller, R., Gilgen, A. K., Michna, P., Plüss, P., Buchmann, N., and Eugster, W.: Management and climate impacts on net $\mathrm{CO}_{2}$ fluxes and carbon budgets of three grasslands along an elevational gradient in Switzerland, Agric. For. Meteorol., 150, 519-530, doi:10.1016/j.agrformet.2010.01.011, 2010. 